\begin{tabular}{llllllllllllllllllllllllllll}
\hline $\mathrm{A}$ & $\mathrm{C}$ & $\mathrm{T}$ & $\mathrm{A}$ & $\mathrm{A}$ & $\mathrm{R}$ & $\mathrm{C}$ & $\mathrm{H}$ & $\mathrm{A}$ & $\mathrm{E}$ & $\mathrm{O}$ & $\mathrm{L}$ & $\mathrm{O}$ & $\mathrm{G}$ & $\mathrm{I}$ & $\mathrm{C}$ & $\mathrm{A}$ & & $\mathrm{C}$ & $\mathrm{A}$ & $\mathrm{R}$ & $\mathrm{P}$ & $\mathrm{A}$ & $\mathrm{T}$ & $\mathrm{H}$ & $\mathrm{I}$ & $\mathrm{C}$ & $\mathrm{A}$
\end{tabular}

\author{
JÁN RÁKoš
}

\title{
Przeworsk culture Cemetery at Rankovce (Eastern Slovakia. Preliminary report
}

\begin{abstract}
There is only a handful of burial sites dated to the Roman Period on the territory of the Eastern Slovakia. Only hitherto excavated cemetery dating to this period is located in Zemplín. In the year 2014 new Przeworsk culture cemetery was identified in Rankovce. During four seasons of the archaeological research forty-six burials were excavated at the site. Cemetery can be dated to the phases B2b - C1a of Roman Period and assigned to the Eastern zone of the Przeworsk culture based on the inventory of the burials.
\end{abstract}

Keywords: Przeworsk culture, cemetery, Eastern Slovakia, Roman imports, Rankovce

\section{INTRODUCTION}

Since the middle of the $20^{\text {th }}$ century the archaeological research in eastern Slovakia intensified significantly. This fact has contributed to the identification and partial examination of several important Roman settlements (BlažiceBohdanovce, Prešov, Šebastovce). Despite that no major Roman Period burial sites were identified. Burials from this period were hitherto mostly known thanks to accidental finds or finds from disturbed graves. The discovery of the Przeworsk culture cemetery at Rankovce confirmed that even on the territory of eastern Slovakia it is still possible to identify and explore suchlike sites.

\section{FINDINGS OF THE GRAVES FROM ROMAN PERIOD IN EASTERN SLOVAKIA}

Only a small number of grave finds dated to the Roman Period are known on the territory of Eastern Slovakia. It is partly due to the current state of archaeological research, but also a very destructive agricultural activity, especially in the

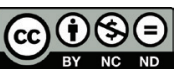

This is an open access article distributed under the terms of the Creative Commons license (CC BY-NC-ND 3.0 PL) 
second half of the last century, may have some share in it. Hitherto known finds are represented by individual cremation burials or cemeteries and inhumation graves dated to the Late Roman period. The largest burial ground is located in Zemplín which according to the published results can be dated between the end of the $1^{\text {st }} \mathrm{AD}$ and the end of the $2^{\text {nd }}$ century $\mathrm{AD}$ (Budínský-Krička, LamiováSchmiedlová 1990) with the scarce occurrence of burials belonging to the both early and late phase of Late Roman Period (Pieta 2006, 502). Finds belonging between the phases B1 and C1a were obtained from the disturbed burials in the cadastre of Kvakovce when the level of water in dam Domaša fell down (Lamiová-Schmiedlová, Mačala 1991). A Roman Period pit burial was excavated in 1942 in the cadastre of the village of Lesná at the top of the mound dated to the transition between Chalcolithic and the Early Bronze Age Period. Pit was identified as burial of a warrior and dated to around 200 AD (Budínský - Krička, 1967, 309).

In the second half of the $19^{\text {th }}$ century iron objects together with a torso of ceramic urn containing residues of calcined bones were found in the cadastre of Lastovce. These finds originally belonged to the inventory of warrior's cremation burials dated to the $3^{\text {rd }}$ century. Burial site whence this objects come is still unidentified (Eisner 1933, 211-212). Roman Period iron weapons and tools found in the cadastre of village Svätá Mária which are now part of a private collection, point to the existence of another burial site. Find circumstances of these objects are not known (Eisner 1933, 212). Early Roman Period urn burial was found in the cadastre of the village of Ždaňa during the excavations on the Hallstatt Period cemetery in 2006. Burial consisted of a pot-shaped vessel in which two spindle whorls were found. The existence of a Germanic burial site in Ždaňa is also confirmed by surface finds - an iron knife and three iron trumpet fibulae (Miroššayová 2010, 241).

The foremost examples of Roman Period inhumation graves on the territory of Eastern Slovakia are princely graves found at Ostrovany dated around to 270 - 290 AD (Prohászka 2006), Cejkov dated to phase C2 - C3 (Beninger 1931, 183-224) and Poprad - Matejovce. Princely grave at Poprad - Matejovce was based on the C 14 analysis dated to the second half of the $4^{\text {th }}$ century AD (Pieta 2009, 107 - 122). Final phase of Roman Period and Migration Period are represented by finds of three inhumations graves at the village Valaliky - Buzice. Graves were not excavated by archaeological methods. The workers carrying out the diggings destroyed the graves. Incomplete finds in the form of ceramic vessels were only at a later date handed to the property owner and subsequently they were provided for documentation. Vessels resemble products of the late Roman pottery workshops and can be dated to the first third, respectively first half of the $5^{\text {th }}$ century (Luštíková, Zábojník 2013). 


\section{ARCHAEOLOGICAL RESEARCH AT THE SITE}

The village of Rankovce is located $18 \mathrm{~km}$ northeast of Košice on the western slopes of Slanské Hills. Roman Period cemetery is situated in a forested terrain and lies at an altitude of 440 meters above sea level. Geological foundation of the site is a contiguous layer of stones (andesite), into which the pits have been excavated.

Cemetery at Rankovce was discovered by illegal treasure hunters in 2014 . They handed over a set of metal finds to the Eastern Slovakia Museum in Košice. Set consisted of an iron umbo and iron shield boss, an iron lance point, a knife and an iron fibula. Fibula is type A 159. All objects were in a well-preserved state and it was evident that they were originally part of a cremation burial. Archaeologists of the museum examined the site immediately after the announcement of the finds and excavated disturbed burial and three more burials at the site (sit. 1-4). A few months later the Eastern Slovak Museum began to carry out systematic archaeological research at the site. The archaeological research at Rankovce has so far not been able to determine the exact boundaries of the burial ground. In 2015 anticipated area of cemetery was investigated using a detection device. This action was necessitated by the immediate threat posed by robbers. Several archaeological situations (graves) were explored outside the area of realized trenches. It can be therefore assumed that the approximate size of the burial ground will be $50 \times 30 \mathrm{~m}$.

During the four seasons of archaeological research (2014-2017) an area of 286 $\mathrm{m}^{2}$ was excavated at the burial site and 85 archaeological situations were uncovered (Fig. 1). This number includes 3 subterranean features with larger dimensions of unknown function (obj. 1, 2, 3), 46 cremation burials (feat. 1, 2, 3, 4, 5, 6, $7,8,9,10,11,12,13,14,15,16,17,18,19,20,21,22,23,24,25,26,27,28,29$, 30, 31, 34, 35, 36, $37,38,39,40,41,42,43,45 \mathrm{a}, 53,54,57,77)$ and 36 small-sized features of unknown function (feat. 32,33 , 44, 45b, 46, 47, 48, 49 51, 52, 55, 56, 58, 59a, 59b, 60, 61, 62, 63, 64, 65, 66, 67, 68, 69, 70, 71, 72, 73, 74a, 74b, 75, 76, 78, 79).

Simple burial pits are prevalent. Only five of all excavated burials were in the form of urn burial (feat. 3, 17, 19, 29, 77) (Fig. 2: 1,3). Burial pits were in some cases only relatively shallowly dug in the subsoil, but especially in the case of burials with richer inventory they were larger and deeper. However, this rule is not fixed. In the case of a very rich warrior's grave 8, the iron sword was found in the depth of only 14 centimetres from the ground level.

Of 46 burials that were excavated so far at the site, based the inventory 21 were identified as male burials (feat. 1, 3, 4, 7, 8, 10, 16, 17, 18, 21, 22, 24, 25, 26, $28,30,34,35,36,39,41$ ), 13 as female burials (feat. 2, 5, 6, 12, 13, 15, 19, 23, 31, $37,40,53,54)$ and in the remaining 12 cases the sex of the buried could not be determined (feat. 9, 11, 14, 20, 27, 29, 38, 42, 43, 45a, 57, 77). 


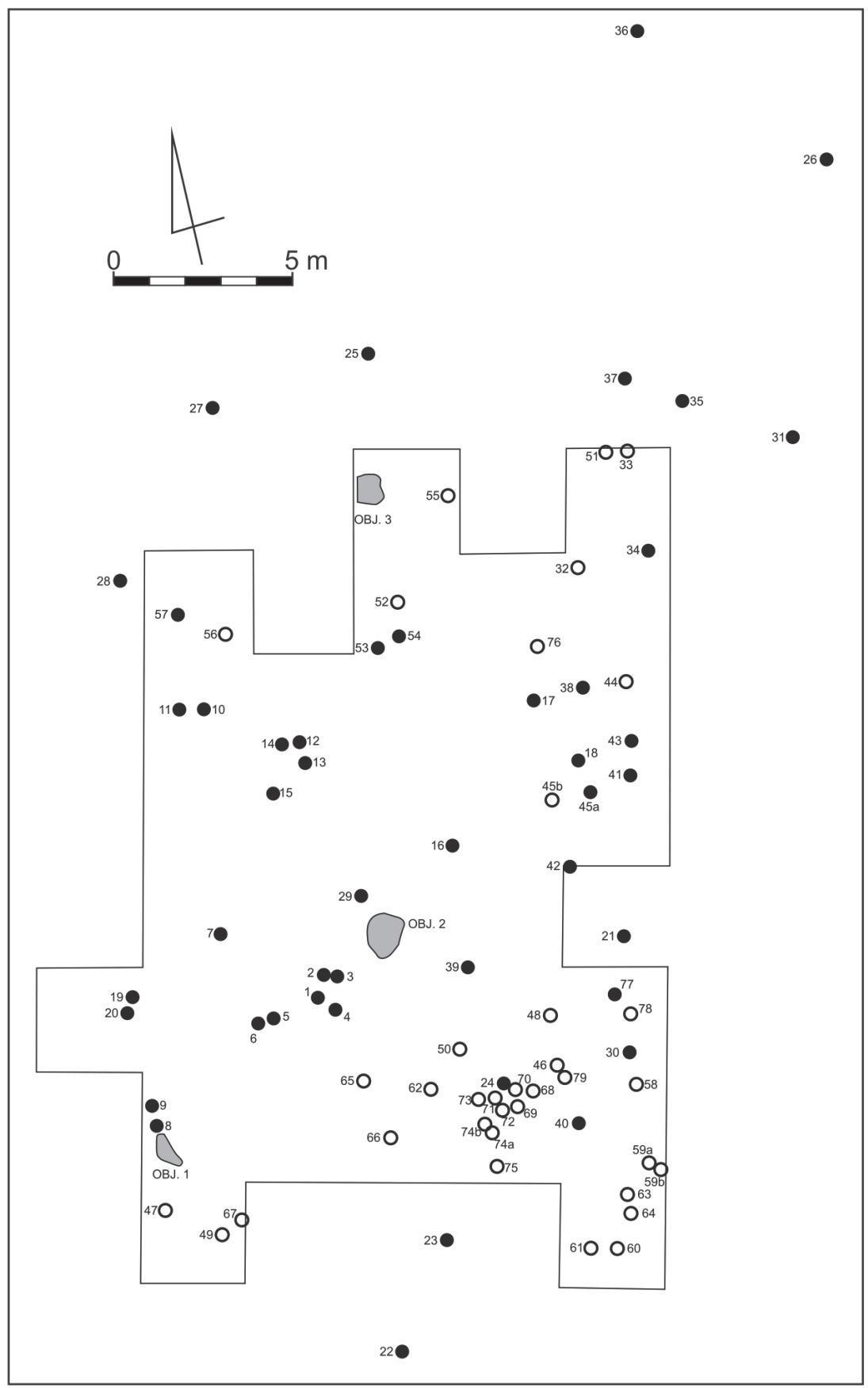

Fig. 1. Rankovce. Plan of explored area of cemetery and objects in years $2014-2017$ 


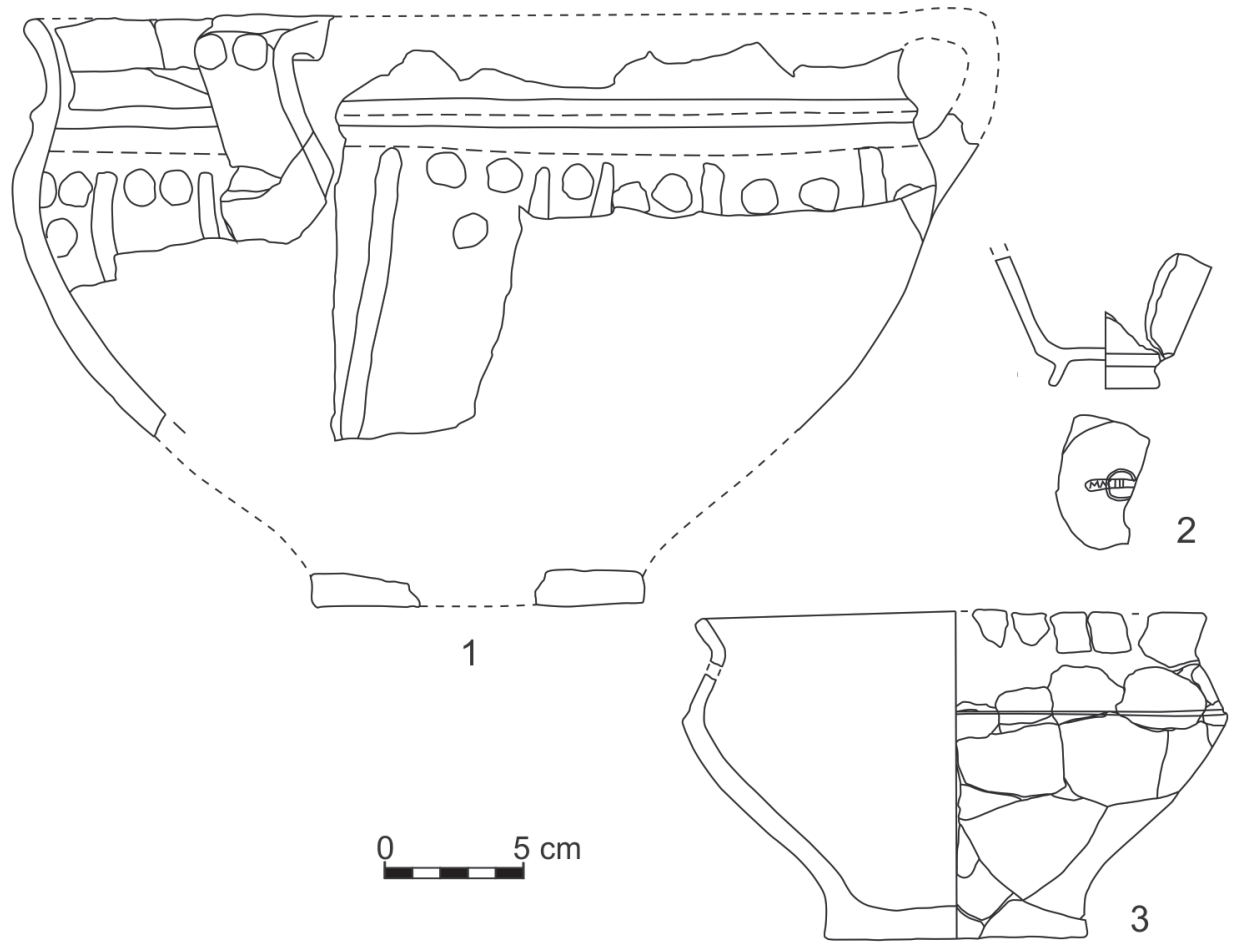

Fig. 2. Rankovce. Ceramic urns (1 - feat. 19, 3 - feat. 3 ) and stray find of terra sigillata (2)

Upper parts of several graves examined at the site were destroyed. However, the vast majority of them, despite being relatively shallow, remained intact. We do not know the original marking of graves on the field. In most cases, the fills of the pits were well recognized. The pits had no treatment and were dug directly into the stone bedrock. In the burial pit 8 there was a flat stone of a square shape at the bottom of the pit. In the case of urn burials calcined bones were found in the lower parts of the vessels with the inventory placed over them. In the case of burial pits bones laid on the bottom of the pit with inventory placed over them which were often covered with a layer of calcined bones. Bone residues are heavily burned, indicating high cremation temperatures. Anthropological analyses have not been performed on calcined bone residues yet. A large number of stray finds for example intact metal objects and their fragments, as well as fragments of ceramic pots among other fractions of terra sigillata Drag. 33 found in the layer above the graves (Fig. 2: 2) can testify to the agricultural activity in the past, which damaged their upper parts. 


\section{CONTENT OF GRAVES}

Cemetery in Rankovce is interesting especially for the rich inventory of some burials. The iron objects found here were well-preserved thanks to the high temperature by cremation and also non-aggressive soil on the site.

Inventory of male burials consists mainly of parts of warrior's equipment and weapons such as swords, lance and spear points, parts of shields, iron and bronze spurs, clothing components, personal equipment but also tools for everyday use. Many of the objects were intentionally broken or deformed before they were placed in the grave. Twenty-one burials were determined as male based on inventory. In three cases, the burials contained complete warrior's equipment consisting of a sword, a spear and a shield (feat. 4, 8, 16).

Even before the systematic research began, feature 4 was examined. The warrior's burial was undisturbed. At the top of it filling, there were three iron belt fittings, all the other inventory was placed in the centre of the bottom of the pit. This inventory was represented by an iron shield boss and a shield grip, two spear points, two iron spurs, iron holder of a scabbard and iron scabbard sheathing, an iron knife, and bucket-shape pendants. A deformed iron sword was found at the very bottom of the pit. The sword is of Roman origin and belongs to a group of swords with ring-shaped pommel (Fig. 3). Based on M. Biborski's typology sword matches Type I with use in phases B2 and C1 (Biborski 1994, 87).

Feature 8 belongs among the most interesting of the rich equipped burials at the site. It is warrior's burial excavated in 2014. Complete inventory was placed in a relatively shallow pit. It consisted of a deformed sword, two spear points, an iron knife, shield boss and bronze shield grip, an iron belt buckle, fragments of a bronze vessel and iron scissors. Deformed sword with a broken point of the blade was placed on the eastern edge of the pit, $14 \mathrm{~cm}$ from the ground level (Fig. 4). Weapon is a Roman double-edged iron sword belonging to a group of swords with encrusted-decoration (Biborski 2012). There is an image of a laurel wreath with ribbons and a palm springs on one side of the blade, the other side is decorated by figure of the god Mars, who holds a spear in his right hand and has a shield resting by his left foot. Roman sword with encrusted decoration is also known in the territory of Western Slovakia. Weapon was found in the burial no. 2 at Kostolná pri Dunaji and it was identified as type of Buch-Podlodów, variant 1 according to Biborski and Ilkjaer. The burial is dated to the final phase of stage B2 (Kolník, Rajtár 2017). In the upper part of the pit of the burial 8 at Rankovce fragments of a bronze vessel were found under which a shield boss made of copper alloy was placed with its calotte facing the bottom of the pit (Fig. 5). The shield boss has a square base size of $15.3 \times 15.3 \mathrm{~cm}$ and the diameter of the calotte is $12 \mathrm{~cm}$. Umbo was damaged by heat. Two bronze rivets with two square washers have been preserved on it. The base and the calotte of the 


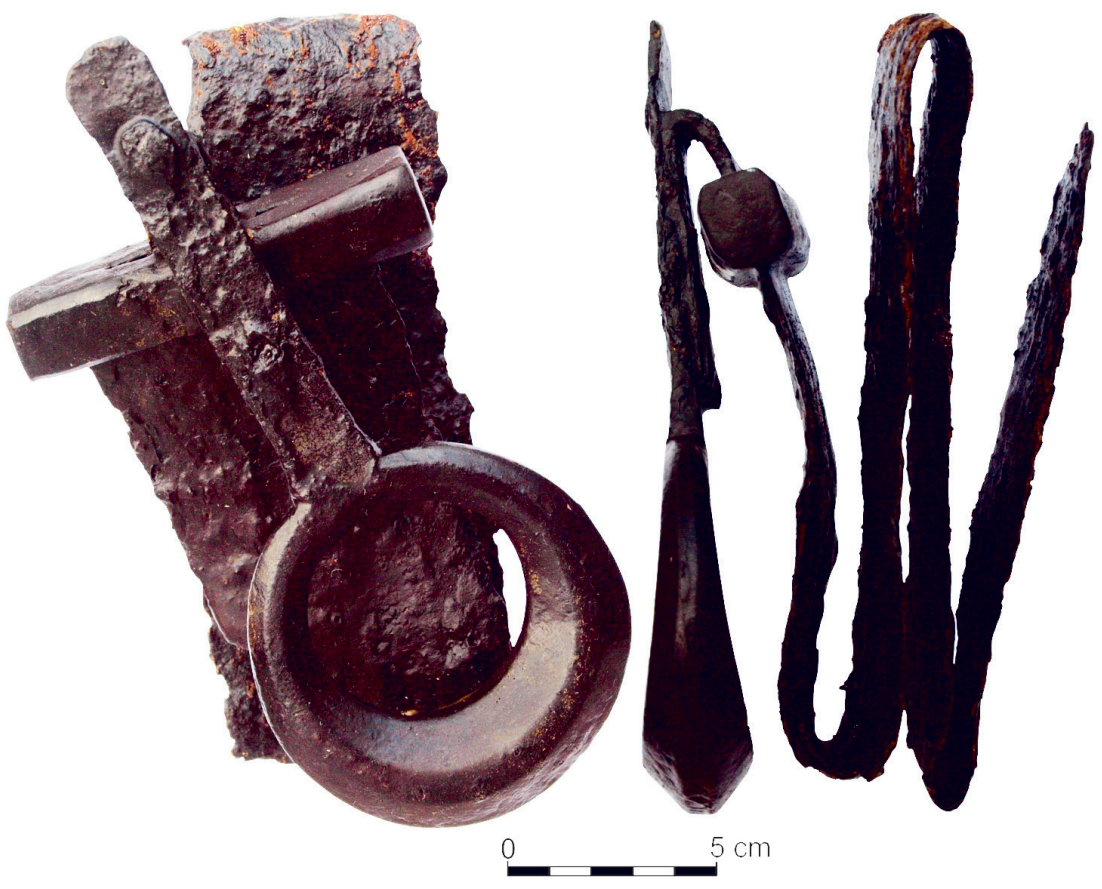

Fig. 3. Rankovce. Iron sword from feature 4

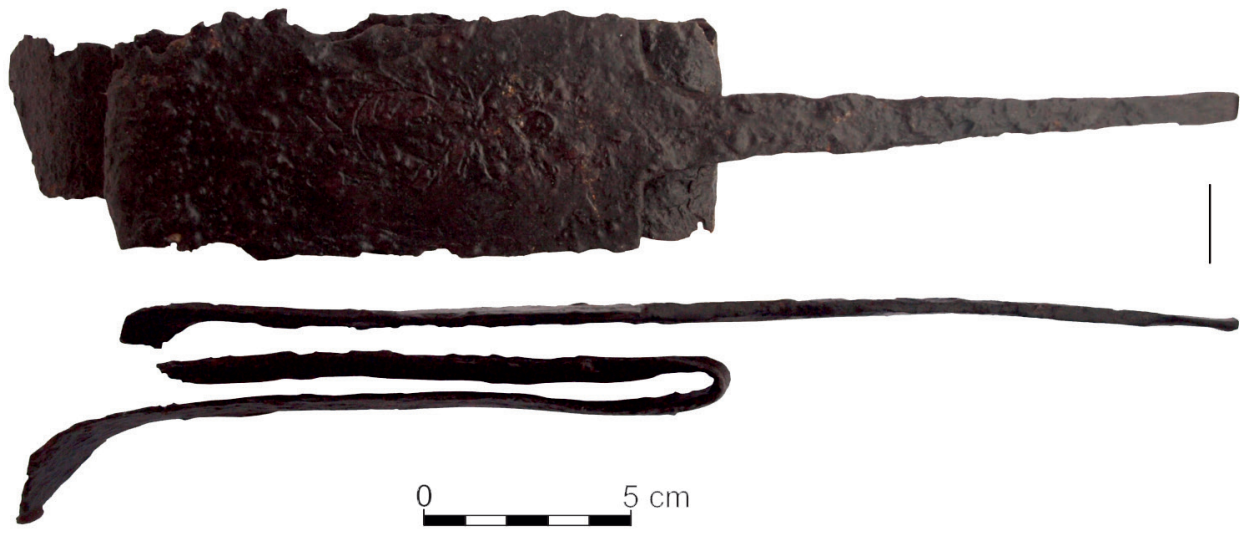

Fig. 4. Rankovce. Iron sword from feature 8 


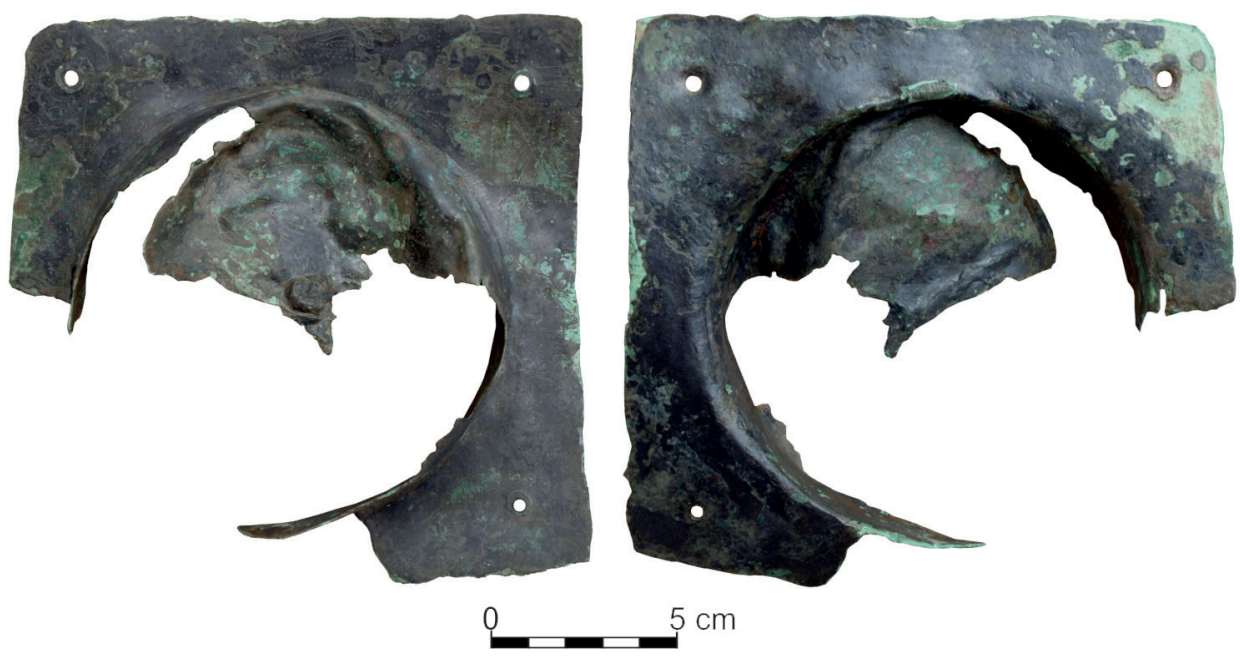

Fig. 5. Rankovce. Shield boss from feature 8

umbo are decorated with engraved floral motifs and lines of small punched dots. The umbo originates in the Roman provinces. Similar punched motif-decorated square-shaped umbo with original size of $28.8 \times 26.8 \mathrm{~cm}$ and calotte diameter of $5.2 \mathrm{~cm}$ diameter, made of copper alloy comes from a legionary camp in Windisch bei Brugg, Switzerland. The umbo dates to the $1^{\text {st }}$ century AD Christ (Nabbefeld 2008, Taf. 88, Nr. 622). Another umbo made of copper alloy was found in the River Tyne near Newcastle upon Tyne. The umbo has a rectangular base and a hemispherical calotte decorated with the combination of punching and engraving techniques. Its decoration consists of figural motifs and text, and this specimen is dated to the second half of the $2^{\text {nd }}$ century AD (Nabbefeld 2008, Taf. 55, Nr. 460).

The women's graves are mainly indicated by iron parts of the boxes and iron keys, iron and bronze fibulae which are often found in pairs, remains of glass vessels (feat. 2, 54) and molten glass beads, iron knives, belt buckles, sewing needles and clay spindle whorls.

Feature 6 belongs among the richest equipped female graves. Bronze vessel of type E 79 (Eggers 1951) to which a bronze bird-shaped attachment belonged was placed in the centre of the burial pit (Fig. 6: 1,2). The vessel has a reinforced edge and a flat bottom that is decorated with incised circles. The attachment has max. length $7.5 \mathrm{~cm}$, max. width $2.9 \mathrm{~cm}$ and max. thickness of 2.25 $\mathrm{cm}$ and weighs $66 \mathrm{~g}$. A similar find of a bronze bird-shaped attachment comes from the cemetery at Jadowniki Mokre and dates to the end of the $2^{\text {nd }}$ century and to the $3^{\text {rd }}$ century AD, phases C1a-C2 (Grygiel 2017, 365). Inventory of the burial 

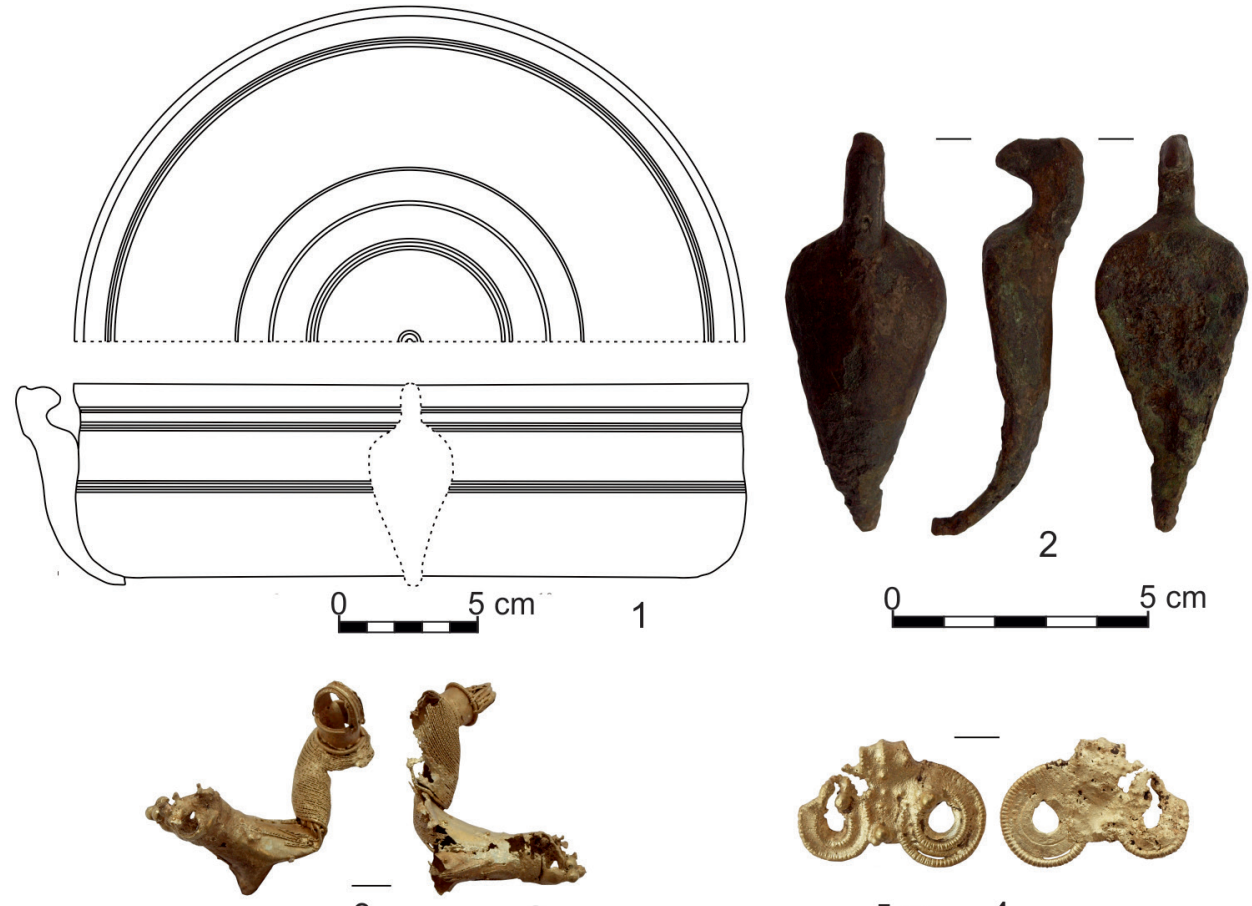

$5 \mathrm{~cm} \quad 4$

Fig. 6. Rankovce. 1, 2, 3 - bronze vessel, bronze bird-shaped attachment and gold pendant from feat. $6 ; 4$ - gold pendant from feat. 31

also included two wholly preserved iron fibulae and a winding terminated with needle of another fibula, an iron knife with a bone cover of handle, a key, a clay whorl spindle, an iron mounting, and a damaged gold pendant (Fig. 6:3). Upper part of this pear-shaped pendant is decorated with filigree and its lower part with granulation. It belongs to type III by A. von Müller (Müller 1956). Preliminary analysis showed that it consists of approximately $64 \%$ gold and $34 \%$ silver (with great thanks for the analysis to M. Biborski). Its weight is $6 \mathrm{~g}$. Two similar pearshaped pendants come from the Zohor burial site on Western Slovakia. The first of them was found in the inventory of the richly equipped female grave 8/2005 and the second specimen is a stray find. These items belong to women's jewellery and are dated to the transitory stage B2/C1 (Rajtár 2013, 140).

Inventory of the Feature 31, which is interpreted as a female grave, consisted of iron parts of a box, an iron knife, a clay spindle whorl, three iron windings of fibulae and a torso of a bronze trumpet fibula belonging to the IV ${ }^{\text {th }}$ Almgren 
group. The most interesting part of the inventory was a damaged golden lunula pendant decorated with granulation, measuring $2.5 \times 1.8 \mathrm{~cm}$ and with weight $7 \mathrm{~g}$ (Fig. 6: 4). In the upper part of the pendant there is a hanging hook, both the outer side of the pendant and the inner holes are decorated with an indented wire. Three protruding beads are applied by the granulation technique at the edge of the inner holes and between them. Similar pendant was found in a layer at Wielbark culture cemetery in Sałdów. Its dating in phases B2/C1-C2 is based on dating of the cemetery (Kurpiewski, Lewandowska 2013, 186, fig. 11:35).

\section{OBJECTS WITHOUT SPECIFYING A FUNCTION}

Hitherto two larger archaeological features (obj. 1,2) were examined in their entirety and third feature was partially examined (obj. 3) at the site. The features are irregular in shape with dimensions of approx. $100 \times 120 \mathrm{~cm}$ and their maximum depth is about $50 \mathrm{~cm}$. They are dug into stone bedrock. Their fill is made of black clay mixed with ash and stones and contained fragments of ceramics, fragments of iron objects and bronze lumps. Exact function of these features is unknown.

The second largest group of examined objects consists of thirty-six features of smaller size scattered across the entire burial site with a greater concentration in its southern part. Some of them are dug in; others are in a form of a layer deposited on stone bedrock. They are mostly of irregular circular shape with their diameter ranging between 10 and $20 \mathrm{~cm}$. Their fill consists of clay mixed with ash and charred residues with colour ranging between light grey and black. Bronze object were found in each of these features (e.g. feat. 32 - bronze fibula; feat 44 - miniature bronze spur) and were wholly preserved or in the form of fragments. Most often bronze appears in the form of lumps in the fill of the features. Often, they are accompanied by fragments of pottery vessels, fragments of glass even by residues of calcined bones. The function of these objects is unknown. They may be related to funeral rituals or they possibly represent remnants of disturbed burials. Identification as cenotaphs or burials of children is also possible.

\section{CONCLUSION}

Eastern Slovakia Museum in Košice carried a systematical archaeological research at the Germanic cemetery at Rankovce in the years 2014-2017. Eightyfive archaeological features including forty-six burials were examined in the area of approximately $300 \mathrm{~m}^{2}$ (Fig. 1). Only five urned burials were excavated, all the other burials were in the form of the pit deposits dug in the bedrock of the site. Anthropological analysis has not been carried out so far. Based on the 
inventory twenty-one burials were determined as male, thirteen as female and in the case of twelve burials sex of the deceased could not be determined. Cemetery at Rankovce is distinguished by the richness of the well-preserved finds, often imports from the Roman Empire. Cemetery can be dated between the late phase of Early Roman Period (B2b) and the beginning of the early phase of the Late Roman Period (C1a) and assigned to the Eastern zone of the Przeworsk culture based on the inventory of the burials.

\section{REFERENCES}

Beninger E.

1931 Der Wandalenfund von Czéké-Cejkov, Annalen des Naturhistorichen Museums in Wien 45, p. 183-224.

Biborski M.

1994 Typologie und Chronologie der Ringknaufschwerter, [in:] Markomannenkriege Ursachen und Wiekungen H. Friesinger, J. Tejral, A. Stuppner (eds.), Stud. AÚ Acad. Věd ČR Brno N. Ř. (N. F.) 1, Brno, p. 85-97.

2012 Nowe odkrycia Rzymskich mieczy zdobionych inkrustowanymi przedstawieniami figuralnymi i znakami symbolicznymi, [in:] In Peregrinationes archaeologicae in Asia et Europa Joanni Chochorowski dedicate, W. Blajer (ed.), Kraków, p. 359-370.

Budínský-Krička V.

1967 Východoslovenské mohyly. Slovenská archeológia 15, p. 277-338.

Budínský-Krička V., Lamiová-Schmiedlová M.

1990 A Late 1st century B.C. - 2nd century A.D. cemetery at Zemplín, [in:] Slovenská archeológia 38, p. 245-348.

Eggers H.J.

1951 Der römische Import im freien Germanien, Atlas der Urgeschichte 1, Hamburg.

Eisner J.

1933 Slovensko v pravěku, Bratislava.

Grygiel M.

2017 Ein einzigartiger römicher Import aus dem Gräberfeld in Jadowniki Mokre,

Kr. Tarnów, [in:] Orbis Barbarorum, Studia ad Archaeologiam Germanorum et Baltorum Temporibus Imperii Romani Pertinentia Adalberto Nowakowski Dedicata, J. Andrzejowski, C. von Carnap-Bornheim, A. Cieśliński, B. Kontny (eds.), Monumenta Archaeologica Barbarica, Seria Gemina VI, Warszawa Schleswig, p. 353-371.

Jakubczyk I.

1998 Die eingliederigen Fibeln der Almgrens VI. Gruppe in der Przeworsk-Kultur Fibeln des Typs A 158, Recherches Archéologiques Nouvelle Serie 5-6, Kraków, p. 113-218.

Kolník T., Rajtár J.

2017 Das Urnengrab 2 aus Kostolná pri Dunaji mit einem römischen Schwert mit Buntmetallinkrustation, [in:] Na hranicich impréria - extra fines imperii. Jaroslavu Tejralovi k 80. narozeninám, J. Bednařiková (ed.), Brno, p. 209-226. 
Kurpiewski A., Lewandowska J.

2013 Sadtowo - Nowa karta w badaniach osadnictwa kultury wielbarskiej na ziemi dobrzyńskiej, Wiadomości Archeologiczne 64, p. 172-190.

Lamiová-Schmiedlová M., Mačala P.

1991 Nálezy z porušeného pohrebiska staršej doby rímskej v Kvakovciach, okr. Vranov nad Toplou, Východoslovenský pravek 3, p. 133-144.

Luštíková L., Zábojník J.

2013 Nové nálezy z obdobia stahovania národov, Keramické nálezy z Valalikov-Buzíc, Zborník Slovenského národného múzea 107, Archeológia 23, p. 245-251.

Miroššayová E.

2010 Výsledky výskumu žiarového pohrebiska v Ždani (Predbežná správa), [in:] Popolnicové polia a doba halštatská, V. Furmánek, E. Miroššayová (ed),

Von Müller A. Archaeologica Slovaca Monographiae 11, Nitra, p. 239-247.

1956 Die birnen- und kugelförmigen Anhänger der älteren römischen Kaiserzeit, Offa 15, p. 93-114.

Nabbefeld A.

2008 Römische Schilde. Studien zu Funden und bildlichen Überlieferungen vom Ende der Republik bis in die späte Kaiserzeit, Kölner Studien zur Archäologie der Römischen Provinzen 10, Rahden/Westf.

Pieta K.

2007 Zemplin, Reallexikon der Germanischen Altertumskunde 34, p. 499-503.

2009 Das Germanische Fürstengrab aus Poprad-Matejovce, [in:] Glaube, Kult und Herschaft, Phänomene des Religiösen im 1. Jahrtausend n. Chr. In Mittel- und Nordeuropa, U. Freeden, H. Friesinger, E. Wamers (eds.), Bonn, p. 107-122.

Prohászka P.

2006 Das vandaliche Königsgrab von Osztrópataka (Ostrovany, SK), Budapest.

Rajtár J.

2013 Das Gold bei den Quaden, [in:] Macht des Goldes, Gold der Macht: Herrschaftund Jenseitsrepräsentation zwischen Antike und Frühmittelalter im mittleren Donauraum, M. Hardt, O. Heinrich-Tamáska (eds.), Weinstadt, p. 125-150.

Address of the Author

\section{Ján Rákoš}

Východoslovenské múzeum Košice

Námestie Maratónu mieru 2

04001 Košice, Slovakia

jan.rakos@vsmuzeum.sk 